\begin{tabular}{|c|c|c|}
\hline $\begin{array}{l}\text { GEOSPORT } \\
\text { SOCIETY }\end{array}$ & $\begin{array}{c}\text { GEOSPORT FOR SOCIETY } \\
\text { Scientific Journal founded in } 2014 \text { under aegis of University of Oradea (Romania), } \\
\text { University of Debrecen (Hungary), University of Gdánsk (Poland) } \\
\text { ISSN 2393-1353 } \\
\text { Edited by Oradea University Press } \\
\text { 1, University Street, 410087, Oradea, Romania }\end{array}$ & EDITURA \\
\hline E & Journal homepage: http://geosport.uoradea.ro & \\
\hline
\end{tabular}

\title{
Application of Water Quality Index in Assessment of Swimming Pools Water Quality in Hotels in Emerging Africa Littoral Metropolis of Warri, Delta State, Nigeria
}

\author{
Obot Akpan IBANGA ${ }^{1 *}$, Stephanie Emuobonuvie OHW01, \\ Goodluck Mamuro OMONIGHO ${ }^{1,2}$
}

1. University of Benin, Department of Geography \& Regional Planning, P.M.B 1154, Benin City, Edo State, Nigeria, email: obotabasiibom@yahoo.com

2. Nigeria Maritime University, Okerenkoko, Delta State, Nigeria, e-mail: omonighogoodluck@gmail.com

* Corresponding author

Citation: Ibanga, O. A., Ohwo, S.E., \& Omonigho, G.M. (2020). Application of Water Quality Index in Assessment of Swimming Pools Water Quality in Hotels in Emerging Africa Littoral Metropolis of Warri, Delta State, Nigeria. Geosport for Society, 13(2), 91-107. https://doi.org/10.30892/gss.1301-062

Article history: 15.08.2020; Revised: 17.09.2020; Accepted: 20.10.2020, Available online: 06.11.2020

\begin{abstract}
Swimming pools in guest houses and hotels in many cities in sub-Saharan Africa have been labelled 'beautiful irritation' or hazard zones for public health issues due to the unwholesomeness of water. Pollution in swimming pools is therefore, not uncommon and it is a serious public health issue both at the global, regional, national and local levels. This study focused on application of water quality index in assessment of swimming pools water quality in hotels in emerging Africa littoral metropolis of Warri, Delta State, Nigeria. It used stratified random sampling technique to select five hotels with swimming pool in Warri for assessment. Temperature, $\mathrm{pH}$, turbidity, free (residual) chlorine, total heterotrophic bacteria, total heterotrophic fungi, Escherichia coli and Staphylococcus aureus tested in the laboratory using scientific method of sampling. Water quality index (WQI) was computed using Weighted Arithmetic Water Quality Index (WAWQI) to evaluate in general, the quality of water in each of the five sampled swimming pools. A five-point scale (excellent, good, poor, very poor and unsuitable) was used to rank each swimming pool quality. Result showed that Wellington Hotel had the value of 2.52 and considered excellent in terms of water quality index value. Also, Brook View and Best Western Plus Hotels were classified as good water based on water quality index values of 36.9 and 39.9 respectively while BB swimming pool was ranked poor due to water quality index of 51.4. In contrast, Oasis Place Hotel swimming pool was declared unsuitable for recreational purpose due to a water quality index of 102.1. The study recommended routine and periodic surveillance of swimming pools and other recreational water sources to guarantee optimum health and wellbeing of users.
\end{abstract}

Keywords: Water quality, index, swimming pool, hotels, Warri Metropolis 


\section{Introduction}

It is an established fact that water has several utilitarian values such as for recreation, drinking, fisheries, agriculture and industry. Water - based recreation is of vital importance to human life and the mortality rate is two times higher among non-swimmers than active swimmers (Chase et al., 2008; Anciaes et al., 2020). It is always enjoyable when compared with non-water related adventures (Lotshaw et al., 2007; Barnett et al., 2018) and critical antidotes for several persistent ailments including arthritis through enhance utilization of affected bodily parts devoid of aggravating pains (Westby, 2001; Stott, 2019). In spite of its usefulness, recreational water bodies in general and swimming poll in particular, are always vulnerable to various forms of pollutants. Polluted water is not healthy for drinking, bathing, industry, agriculture (United Nations-Water, 2014; Boelee et al., 2019) not to talk of its fitness for swimming and other recreational activities. Guest house and hotel pools, however, are oftentimes labelled 'beautiful irritation' or hazards. Pollution in swimming pools is not uncommon and it is a serious public health issue both at the global, regional, national and local levels.

Swimming pool has been described as a container filled with water intended for swimming or water-based recreation. It can be constructed either above or in the ground, using concrete materials (Eze et al., 2015; Godfrey, 2019). Swimming pools designated for public use are called public pools while private pools are those used exclusively by a few people or in homes. Hot tubs and spas are pools with hot water, used for leisure or rehabilitation and are common in homes, hotels, clubs and massage parlours (Eze et al., 2015). Tourism and hospitality practitioners, fitness centers, health clubs and private clubs often incorporate swimming pools into their businesses as value - added services to capture customers' interest, boost patronage and quick returns for investment.

Empirical evidence show that about $20 \%$ swimmers urinate in swimming pools, $23 \%$ of users are worried about the hygiene and sanitation status of the public pools while about $35 \%$ of swimmers do not bath before jumping into the pool (Agbagwa and Young-Harry, 2012). Majority of swimmers contaminate pool water with large amounts of microorganisms as a result of various secretions from skins, mouths, noses and throats, urines or by contaminated objects and clothes, making water a possible vehicle for the dissemination of infectious diseases among swimmers (Dirtu et al., 2016). From the skin alone uncountable bacteria are rinsed during swimming and if the water is untreated, these microorganisms will build up and increase the chance of transmission to swimmers (Rabi et al., 2008; Bonadonna and La Rosa, 2019).

Swimming pool contamination can also come from pets especially dogs that occasionally wander around unprotected pools as well as from debris already around the properties. It could also be as result of the direct animal contamination including flying birds (Pesewu et al., 2015). It is therefore, essential to be able to evaluate the risks associated with a pool. The risks associated with pool drowning, impact injuries, physiological, infection and poisoning, toxicities and other conditions that may arise from long-term chemical exposures, contact with, inhalation or ingestion of algal toxins (Eze et al., 2015). In Nigeria and many other 
countries in sub-Saharan Africa, statistics on water quality of swimming pools are lacking. A lot of attention is given to surface and groundwater quality for drinking purpose by most researchers (Aghoghovwia, 2011; Fovwe et al., 2014; Asadu, 2016).

Currently, there is no data about infections and outbreak of diseases related to swimming pools in hotels in emerging African littoral metropolis of Warri, Delta State, Nigeria. The strategic importance of Warri in the economy of Nigeria as one of the oil producing metropolis and as a destination to many tourists, fun and pleasure seekers as well as investors around the world should have motivated researchers to explore water quality in swimming pools. Stakeholders also appear to ignorantly believe that all is well in Warri in terms of water quality in swimming pools. Compliance, governance and regulatory frameworks concerning the business and operation of swimming pools in the metropolis may also unable to meet with the emerging challenges of water quality. Public health, good sanitation and personal hygiene practices are other challenging issues surrounding water quality in swimming pools.

Saba and Tekpor (2015) reported that those who normally take care of these swimming pools have little knowledge about the importance of maintaining the pools to meet both the microbiological and physiochemical standards. Some operators may be tempted to economize chemicals used for sanitizing the pools as a result of their scarcity or perhaps over-chlorinate the pools due to little knowledge of the recommended quantities to apply and hence compromise the quality of the swimming pools (Saba and Tekpor, 2015). All these issues have unquantifiable consequences and impact to sustainable users' welfare and tourism development. Thus, it is not a simple thing to say "that water is good" or "that water is bad." The determination of water quality is typically made relative to the purpose of the water - in this case for recreational (swimming pool).

There are a number of physical, chemical, and biological indicators that are most commonly used in assessing the quality of water in swimming pools. The physical indicators include temperature, total suspended solids (TSS), total dissolved solids (TDS), electrical conductivity, and turbidity. Chemical indicators include $\mathrm{pH}$, biochemical oxygen demand (BOD), chemical oxygen demand (COD), dissolved oxygen (DO), chlorine and total hardness (TH). The biological indicators are total coliform count (TCC), faecal coliform count (FCC) and other pathogenic bacteria and algae. The assessment of these parameters is capable of establishing and tracking alterations in water quality while verifying its suitability for the wellbeing of recreational users and one of the emerging frameworks uses is water quality index.

However, water quality index (WQI) has often been misconstrued to mean water quality standards (WQSs). Although both are concepts used in water quality monitoring and assessment, they are fundamentally different. Water quality index has therefore been seen as priceless and matchless evaluation set up to depict the overall water quality status in a single term that is helpful for the selection of right management modus operandi to meet the concerned issues (Tyagi et al., 2013). Conversely, water quality standards are governance frameworks covering specific 
uses and water quality criteria to save uses from gratuitous harm (United States Environmental Protection Agency - USEPA, 2016).

The decisive factor espoused and integrated into the standards are the tolerable concentration of pollutants in states, territories and certified clannish waters. The environmental watch dog argued that these norms are corresponding: each is premeditated to save users from harm from particular specie of micro organisms or environmental systems from the unpleasant outcome of contamination. Water quality norms are formulated autonomously based on the best available scientific data and scientific judgments. The criteria are generally listed at some threshold concentration that, if exceeded, would cause harm to aquatic life, wildlife or human health (USEPA, 2016). Thus, while water quality index portrays the combined influence of diverse water quality indicators and conveys water quality issues to the public and legislative decision makers (Tyagi et al., 2013), water quality standards depicts the scientifically established targets approved by regulatory agencies for different water uses (World Health Organization - WHO, 2018).

Till date, there is also no globally accepted composite index of water quality; several countries have only resulted to using aggregated water quality data in the development of water quality indices (Banda and Kumarasamy, 2020). For water quality standards, there are a number of them including the World Health Organization (WHO), Australia, Brazil, Canada, India, Tanzania, the United States, the Federal Environmental Protection Agency (FEPA), Standard Organization of Nigeria and Department of Petroleum Resources standards amongst others. Table 1 shows the WHO water quality standards for selected parameters in relation to safe recreational water environments.

Table 1. WHO Standards for Swimming Pools and Similar Environments Source: WHO (2006)

\begin{tabular}{|l|l|}
\hline Parameters & Maximum Allowable Limit \\
\hline Temperature & $26^{0}-30^{\circ} \mathrm{C}$ \\
\hline Turbidity & $\leq 0.5 \mathrm{NTU}$ \\
\hline $\mathrm{pH}$ & $7.2-7.8$ \\
\hline Free residual chlorine & $1-3 \mathrm{mg} / \mathrm{l}$ \\
\hline Heterotrophic plate count (HPC) & $\leq 200 \mathrm{cfu} / \mathrm{ml}$ \\
\hline Escherichia coli & $\leq 1 / 100 \mathrm{ml}$ \\
\hline Staphylococcus aureus & $\leq 100 / 100 \mathrm{ml}$ \\
\hline
\end{tabular}

According to the Department of Environment and Climate Change (DECC), Government of Newfoundland and Labrador (2016), a water quality index is a means by which water quality data is summarized for reporting to the public in a consistent manner. Empirical evidence point to the fact that water quality index is accredited to the work of Horton (1965) among the most commonly used water quality variables include dissolved oxygen (DO), $\mathrm{pH}$, coliforms, specific conductance, alkalinity and chloride etc. and has been widely applied and accepted in European, African and Asian countries (Chandra et al., 2017). In the computation of water quality index, a stepwise procedure which relies on indicators of public health importance has been proposed. The initial step involves the choice of water quality 
indicators. This is the exclusive responsibility of water quality governance authorities and its resource persons and within its jurisdiction. At this step, specific emphasis is given to the concentrations of DO, healthiness implications, physicochemical features as well as suspended mineral salts capable of interfering with the biological activities in the water source (Dunnette, 1979; Scannone, 2016).

The second step entails the establishment of functional relationship among indicators and statistical normalization of all indicators into unitless scale (Fritzsche et al., 2014). The rationale for statistical normalization of all indicators is based on the fact that various water quality indicators are measure on specific scientific unit that is entirely different from others. The final step involves the summing together of all water quality indicators to arrive at a single value otherwise referred to as index (Garcia et al., 2018).

In practice, the water quality index is calculated by comparing the water quality data to established guidelines for water quality. Water quality index measures the scope, frequency, and fluctuations in the level of water quality and then combines the three measures into one score. This calculation produces a score between 0 and 100. The higher the score, the better the quality of water and the scores are then ranked into one of the five categories (DECC, 2016). The index is a valuable and unique rating to depict the overall water quality status in a single term that is helpful for the selection of appropriate treatment technique to meet the concerned issues. Nevertheless, several water quality indices have been have been postulated by a number of national and international organizations and documented in contemporary literature. Most popular ones include the Weighted Arithmetic Water Quality Index (WAWQI), National Sanitation Foundation Water Quality Index (NSFWQI), Canadian Council of Ministers of the Environment Water Quality Index (CCMEWQI), and Oregon Water Quality Index (OWQI) among others. Moreover, water quality indices have been known to vary from season to season even at low concentrations (Kachroud et al., 2019).

The Weighted Arithmetic Water Quality Index (WAWQI) method originally developed by Brown et al., (1972) categorizes the water quality according to the extent of cleanness taking into consideration`n the generally frequently considered indicators using the formula in equation 1 .

$$
W Q I=\sum Q i W i / \sum W i
$$

The quality evaluation scale (Qi) for each indicator is computed with the function in equation 2:

$$
\mathrm{Q}=100[(\mathrm{Vi}-\mathrm{Vo} / \mathrm{Si}-\mathrm{Vo})]
$$

\section{Where,}

$V i$ is approximate level of $i$ th indicator from laboratory analysis

$V o$ is the real value of this indicator in uncontaminated sample

$V o=0$ (except $\mathrm{pH}=7.0$ and $\mathrm{DO}=14.6 \mathrm{mg} / \mathrm{l}$ )

$\mathrm{Si}=$ allowable limit of $i$ th indicator. 
The respective weight (Wi) for each indicator is computed with the function in equation 3:

$$
W i=K / S i
$$

Where $K=$ mathematical constant and is computed with the function in equation 4 :

$$
K=\frac{1}{\Sigma(1 / \mathrm{Si}}
$$

The computed water quality index value is then evaluated according the category which it falls as presented in Table 2. Remarkably, the advantage and disadvantages of WAWQI framework has been documented as summarized in Table 3. The major underlying principle for evolution water quality index is pivoted by transforming multifarious indicators of water quality into well-articulated, clear, simple and credulous information of the water source to all users (Akoteyon et al., 2011; Balan et al., 2012; Bora and Goswami, 2016).

Table 2. Water Quality Rating Based on WAWQI Method

Source: (Brown et al., 1972)

\begin{tabular}{|l|l|l|}
\hline WQI Value & Evaluation of Water Quality & Category \\
\hline $0-25$ & Excellent water quality & $A$ \\
\hline $26-50$ & Good water quality & $B$ \\
\hline $51-75$ & Poor water quality & $C$ \\
\hline $76-100$ & Very Poor water quality & $D$ \\
\hline Above 100 & Unsuitable for drinking purpose & $E$ \\
\hline
\end{tabular}

Table 3. Advantages and Disadvantages of WAWQI Framework

Source: (Yogendra and Puttaiah, 2008; Akoteyon et al., 2011; Tyagi et al., 2013)

\begin{tabular}{|l|l|}
\hline Advantages & Disadvantages \\
\hline $\begin{array}{l}\text { 1. Incorporate data from multiple water quality } \\
\text { parameters into a mathematical equation that rates }\end{array}$ & $\begin{array}{l}\text { 1. Water quality index may not carry enough } \\
\text { information about the real quality situation of the } \\
\text { the health of water body with number. }\end{array}$ \\
$\begin{array}{l}\text { 2. Less number of parameters required in comparison } \\
\text { to all water quality parameters for particular use. } \\
\text { 3. Useful for communication of overall water quality } \\
\text { an index. }\end{array}$ & $\begin{array}{l}\text { 3. The eclipsing or over-emphasizing of a single bad } \\
\text { parameter value }\end{array}$ \\
makers. & $\begin{array}{l}\text { 4. A single number cannot tell the whole story of water } \\
\text { quality; there are many other water quality parameters } \\
\text { p. Reflects the composite influence of different } \\
\text { parameters i.e. important for the assessment and } \\
\text { thanagement of water quality. }\end{array}$ \\
5. Describes the suitability of both surface and & $\begin{array}{l}\text { 5. Water quality index based on some very important } \\
\text { parameters can provide a simple indicator of water } \\
\text { groundwater sources for human consumption. }\end{array}$ \\
\hline
\end{tabular}

Unfortunately, drinking water quality in Nigeria and other developing countries is questionable not to talk about that of recreational water facilities like swimming pools. This aspect of research has not enjoyed considerable patronage until in recent years. Again, despite the advantages of the approach, empirical evidence on application of water quality index in swimming pools water quality 
assessment in hotels in emerging African littoral metropolis of Warri, Delta State is lacking. Whereas, water quality index framework have been applied in both surface and groundwater quality assessment all around the world since the last few decades (Kumar and Dua, 2009; Rocha et al., 2015; Bora and Goswami, 2016; Egun and Ogiesoba-Eguakun, 2018; Soleimani et al., 2018).

Based on the significant role played by recreational water activities to health and vitality in general, and the key value of swimming pools to the hospitality and tourism industry, the need to fill these knowledge gaps becomes essential. The study therefore, seeks to analyze the water quality of hotels swimming pools in emerging African littoral metropolis of Warri, Delta State to using water quality index with the view to establish the extent of contamination. The application of water quality index in this study will provide an easy way to understand the status of water quality in swimming pools in Warri and the information will be useful to the public in general, pool operators, planners, managers, and policy makers.

\section{Methodology}

\section{Geography of Warri Metropolis}

This study was carried out in one of the emerging African littoral metropolis of Warri, Delta State, Nigeria. Warri metropolis is spatially situated between latitudes 50 27' 50.468' - 50 36' 39.937' North of Equator and longitudes 50 42' 34.5' - 70 49' 44.431" East of Greenwich as seen in Figure 1. Warri metropolis has constituent parts in Warri South, Udu and Uvwie Local Government Areas. It has also grown to engulf the surrounding towns of Effurun, Ekpan, Enerhen, Orhuwhorun, Ogunu, Jakpa, Ovwian-Aladja and Ugbomro in the last few decades (Efe and Efe, 2002). Warri is one of the rapidly growing metropolis in Nigeria, with the population increasing rapidly from 280,000 in 1980 to 363,382 in 1991, 536,023 in 2006 and subsequently to 814,000 at the end of 2019 (Macrotrends LLC, 2019). Warri thus, has a high population density, concentrated in the areas of the city, including WarriSapele road, Agbassa, Okere, Okumagba Avenue, Igbudu, Iyara, Jakpa, Airport road, Petroleum Training Institute (PTI), Udu and Ekpan.

The climate of Warri metropolis falls within the tropical rainforest with frequent influence of tropical continental and maritime air masses. The highresolution time-series (TS) gridded climatic data of month-by-month variation in climate (version 4.03 - January 1901 - December 2018) released by the University of East Anglia-Climatic Research Unit, Harris and Jones (2019) indicate that temperature is as low as $22.1^{\circ} \mathrm{C}$ in January and as high as $33.6^{\circ} \mathrm{C}$ in February in Warri metropolis. Rainfall pattern is bi-modal with the first peak of $507.8 \mathrm{~mm}$ in June with a short dry season in August and the second peak of $493.1 \mathrm{~mm}$ in September and a total about $3745.7 \mathrm{~mm}$ per annum. Relative humidity is generally high due to abundance of rainfall and it ranged from 94\% in April to 97\% in August with a dry season average of about $80 \%$. Annual potential evapotranspiration is about $57.1 \mathrm{~mm}$ with highest value of $5.8 \mathrm{~mm}$ observed in February and lowest value of $3.5 \mathrm{~mm}$ noticed in July. Mean wind speed is about 2.3 meters per second and may sometime exceed 5 meters per second in peak rainy season. 
With respect to the relief, Warri metropolis is generally a low-lying area which situate within the Niger - Delta plain. Digital elevation model (DEM) is a representation of the general relief of the area. DEM represent continuous elevation values over a topographic surface by a regular array of z-values, referenced to a common datum. DEMs are typically used to represent terrain relief. Average elevation is about 10.1 meters and ranged from 2 meters to 29 meters above sea level.

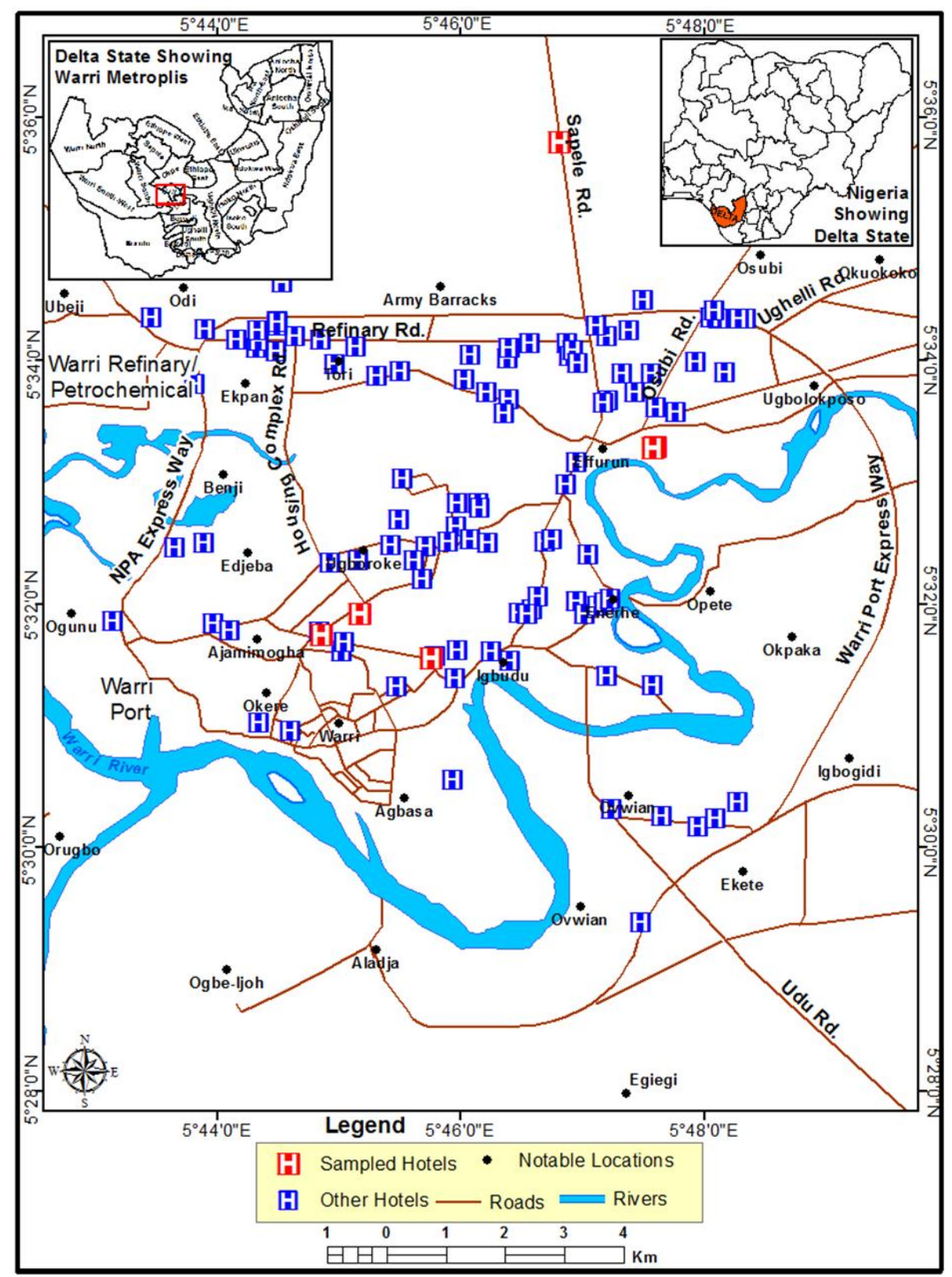

Figure 1. Warri Metropolis Showing Sample Hotels with Swimming Pools 
Vegetation in Warri metropolis is characteristic fresh water intermingled with mangrove swamp forest which represents the most luxuriant, complex and diverse terrestrial ecosystem in sub-Saharan Africa. The socio-economic activities in Warri metropolis can be classified into primary, secondary and tertiary activities. The primary activities include agricultural activities and animal husbandry. Secondary activities include several manufacturing and processing activities carried out by firms and oil companies in the metropolis while tertiary activities include activities and services carried out by servicing firms and individuals. Warri metropolis is also an administrative centre, with the headquarters of Warri South LGA, Udu and Uvwie LGA located in it.

\section{Datasets, Sources, Methods of Analyses}

This research adopted experimental approach to elucidate information on swimming pool water quality in Warri metropolis. The physical properties of swimming pool water that were investigated include temperature and turbidity. Free (residual) chlorine and $\mathrm{pH}$ constituted the chemical parameters while total heterotrophic bacteria (THB), total heterotrophic fungi (THF), Escherichia coli and Staphylococcus aureus made up the microbiological quality parameters. Based on the research objective, these variables were of particular importance to this study. As seen the literature, they are most relevant as far as public health and safety is concerned. According to Delta State Hotels and Tourism Board (DSHTB), there are 214 hotels in Warri based on 2016 records. Out of this figure, 15 of them have functional swimming pools (DSHTB, 2016) representing 7\% of the hotels in the town. Stratified random sampling (Kaplan, 2014) based on room rate per night (Table 4) was deployed in selection of five hotels with swimming pools.

Table 4. Stratification of Hotels Based on Room Rate per Night

(Source: Fieldwork, 2019)

\begin{tabular}{|l|l|c|l|}
\hline S/No & Charges Interval per Night $(\mathrm{N})$ & $\begin{array}{c}\text { Number of Hotels } \\
\text { (Frequency) }\end{array}$ & Description \\
\hline 1 & $1,000.00-5,000.00$ & 4 & Very Low \\
\hline 2 & $5,100.00-10,000.00$ & 6 & Low \\
\hline 3 & $10,100.00-15,000.00$ & 4 & Moderate \\
\hline 4 & $15,100.00-20,000.00$ & 1 & High \\
\hline 5 & $20,100.00-25,000.00$ & 1 & Very High \\
\hline & & $\mathrm{N}=16$ & \\
\hline
\end{tabular}

Standard procedures were adopted in water sample collection and laboratory analysis in line with the requirements specified by WHO, the American Society for Testing and Materials (ASTM), United States Environmental Protection Agency (USEPA) and American Public Health Association (APHA).The water was obtained from five sampled swimming pools from hotels in Warri metropolis for laboratory investigation during peak period (weekend). In-situ analyses were immediately carried out to determine the following parameters with short holding time; temperature, $\mathrm{pH}$, turbidity, and Free (residual) chlorine. Water samples for microbiology analysis (THB, THF, E. coli and S. aureus) were collected in $200 \mathrm{ml}$ 
plastic containers, acidified with $10 \% \mathrm{HNO}_{3}$ stored in cooler at $4{ }^{\circ} \mathrm{C}+0.2^{\circ} \mathrm{C}$ and immediately transported to the laboratory for analysis using the techniques described in Esinulo and Ogbuagu (2016).

\section{Computation of Water Quality Index (WQI) Swimming Pools}

This study used Weighted Arithmetic Water Quality Index (WAWQI) method to compute water quality index of hotels' swimming pools water quality in Warri metropolis. Thus, with the aid of Equations $1-4$ earlier stated the laboratory results of water quality indicators per sampled swimming pool were used as input in water quality index computation. However, this study adopted a bottom - up approach in the computation of water quality index through the following step:

Step 1: Determination of $\mathrm{K}$ for $\mathrm{pH}$, temperature, turbidity and free (residual) chlorine using Equation 4.

$$
\begin{aligned}
& p H=K=\frac{1}{\Sigma(1 / 7.8)}=\frac{1}{0.128}=7.813 \\
& \text { Temperature }=K=\frac{1}{\Sigma(1 / 30)}=\frac{1}{0.033}=30.303 \\
& \text { Turbidity }=K=\frac{1}{\Sigma(1 / 0.5)}=\frac{1}{2}=0.5 \\
& \text { Free (residual) chlorine }=K=\frac{1}{\Sigma(1 / 0.5)}=\frac{1}{2}=0.5 \\
& \text { Step 2: Computation of the unit weight }(\text { Wi }) \text { for pH, t } \\
& \text { (residual) chlorine using Equation } 3 . \\
& p H=W i=\frac{K}{\mathrm{Si}}=\frac{7.813}{7.8}=1.002 \\
& \text { Temperature }=W i=\frac{K}{\mathrm{Si}}=\frac{30.303}{30}=1.0101 \\
& \text { Turbidity }=W i=\frac{K}{\mathrm{Si}}=\frac{0.5}{0.5}=1 \\
& \text { Chlorine }=W i=\frac{K}{\mathrm{Si}}=\frac{3.03}{3}=1.01
\end{aligned}
$$

Step 2: Computation of the unit weight $(W i)$ for $\mathrm{pH}$, temperature, turbidity and free

Step 3: Computation of the quality rating scale (Qi) for each parameter in all the 5 sampled swimming pools using Equation 2.

Brook View Hotel

$$
p H=Q i=\left[\frac{V i-V o}{\mathrm{Si}-\mathrm{Vo}_{\mathrm{o}}}\right] 100=\left[\frac{6.40-7.0}{7.8-7.0}\right] 100=-75
$$


Temperature $=Q i=\left[\frac{V i-V o}{\mathrm{Si}-V_{0}}\right] 100=\left[\frac{25-0}{30-0}\right] 100=83.3$

Turbidity $=Q i=\left[\frac{V i-V o}{\mathrm{Si}-\mathrm{Vo}_{0}}\right] 100=\left[\frac{0.63-0}{0.5-0}\right] 100=126$

Chlorine $=Q i=\left[\frac{V i-V o}{\mathrm{Si}-\mathrm{Vo}}\right] 100=\left[\frac{0.4-0}{3-0}\right] 100=13.3$

$\underline{\text { Oasis Hotel }}$

$p H=Q i=\left[\frac{V_{i}-V_{0}}{S i-V_{o}}\right] 100=\left[\frac{6.60-7.0}{7.8-7.0}\right] 100=-50$
Temperature $=Q i=\left[\frac{V_{\mathrm{Si}}-\mathrm{Vo}_{0}}{\mathrm{Si}-\mathrm{Vo}}\right] 100=\left[\frac{25-0}{30-0}\right] 100=83.3$

Turbidity $=Q i=\left[\frac{V i-V o}{\mathrm{Si}-\mathrm{Vo}_{\mathrm{o}}}\right] 100=\left[\frac{1.85-0}{0.5-0}\right] 100=370$

Chlorine $=Q i=\left[\frac{V i-V o}{\mathrm{Si}-\mathrm{Vo}_{0}}\right] 100=\left[\frac{0.2-0}{3-0}\right] 100=6.67$

$\underline{\text { BB Hotel }}$

$$
\begin{aligned}
& p H=Q i=\left[\frac{V i-V o}{\mathrm{Si}-\mathrm{Vo}}\right] 100=\left[\frac{6.20-7.0}{7.8-7.0}\right] 100=-100 \\
& \text { Temperature }=Q i=\left[\frac{V i-V o}{\mathrm{Si}-\mathrm{Vo}_{\mathrm{o}}}\right] 100=\left[\frac{25-0}{30-0}\right] 100=83.3 \\
& \text { Turbidity }=Q i=\left[\frac{V i-V o}{\mathrm{Si}-\mathrm{Vo}_{\mathrm{o}}}\right] 100=\left[\frac{1.08-0}{0.5-0}\right] 100=216 \\
& \text { Chlorine }=Q i=\left[\frac{V i-V o}{\mathrm{Si}-\mathrm{Vo}_{\mathrm{o}}}\right] 100=\left[\frac{0.2-0}{3-0}\right] 100=6.67
\end{aligned}
$$

Wellington Hotel

$$
p H=Q i=\left[\frac{V i-V o}{\mathrm{Si}-\mathrm{Vo}}\right] 100=\left[\frac{6.10-7.0}{7.8-7.0}\right] 100=-112.5
$$

Temperature $=\quad Q i \quad=\left[\frac{V i-V o}{\mathrm{Si}-\mathrm{Vo}_{0}}\right] 100=\left[\frac{25-0}{30-0}\right] 100=83.3$

Turbidity $=Q i=\left[\frac{V i-V o}{\mathrm{Si}-\mathrm{Vo}}\right] 100=\left[\frac{0.16-0}{0.5-0}\right] 100=32$

$$
\text { Chlorine }=Q i=\left[\frac{V i-V o}{\mathrm{Si}-\mathrm{Vo}_{\mathrm{o}}}\right] 100=\left[\frac{0.2-0}{3-0}\right] 100=6.67
$$

Best Western Hotel

$$
p H=Q i=\left[\frac{V i-V o}{\mathrm{Si}-\mathrm{Vo}}\right] 100=\left[\frac{6.30-7.0}{7.8-7.0}\right] 100=-87.5
$$




$$
\begin{aligned}
& \text { Temperature }=Q i=\left[\frac{V i-V o}{\mathrm{Si}-\mathrm{Vo}}\right] 100=\left[\frac{29-0}{30-0}\right] 100=96.67 \\
& \text { Turbidity }=Q i=\left[\frac{V i-V o}{\mathrm{Si}-\mathrm{Vo}_{0}}\right] 100=\left[\frac{0.72-0}{0.5-0}\right] 100=144 \\
& \text { Chlorine }=Q i=\left[\frac{V i-V o}{\mathrm{Si}-\mathrm{Vo}_{\mathrm{o}}}\right] 100=\left[\frac{0.2-0}{3-0}\right] 100=6.67
\end{aligned}
$$

Step 4: Computation of the water quality index for all the five sampled swimming pools using Equation 1.

(a) Water quality index for Brook View Hotel Swimming Pool $\frac{(-75 \times 1.002)+(83.3 \times 1.0101)+(126 \times 1)+(13.3 \times 1.01)}{(1.002+1.0101+1+1.01)}=\frac{(-75.15)+(84.14)+(126)+(13.433)}{(4.0221)}=36.9$

(b) Water quality index for Oasis Hotel Swimming Pool $\frac{(-50 \times 1.002)+(83.3 \times 1.0101)+(370 \times 1)+(6.67 \times 1.01)}{(1.002+1.0101+1+1.01)}=\frac{(-50.1)+(84.14)+(370)+(6.74)}{(4.0221)}=102.1$

(c) WQI for BB Hotel Swimming Pool $\frac{(-100 \times 1.002)+(83.3 \times 1.0101)+(216 \times 1)+(6.67 \times 1.01)}{(1.002+1.0101+1+1.01)}=\frac{(-100.2)+(84.14)+(216)+(6.74)}{(4.0221)}=51.4$

(d) WQI for Wellington Hotel Swimming Pool $\frac{(-112 \times 1.002)+(83.3 \times 1.0101)+(32 \times 1)+(6.67 \times 1.01)}{(1.002+1.0101+1+1.01)}=\frac{(-112.73)+(84.14)+(32)+(6.74)}{(4.0221)}=2.52$

(e) WQI for Best Western Hotel Swimming Pool $\frac{(-87.5 \times 1.002)+(96.6 \times 1.0101)+(144 \times 1)+(6.67 \times 1.01)}{(1.002+1.0101+1+1.01)}=\frac{(-87.7)+(97.6)+(144)+(6.74)}{(4.0221)}=39.9$

This produced a score (value) ranging from 0 to 100 . Using Table 2, each swimming pool was categorized based on quality. DECC (2016) however asserted that a higher score depicts poor water quality while a lower value is an indication of high water quality.

\section{Results and Discussion}

The computation of water quality index of five sampled hotels' swimming pools in emerging African littoral metropolis of Warri, Delta State, Nigeria was based on four physicochemical water quality parameters of $\mathrm{pH}$, temperature, turbidity and chlorine. The microbiological indicators were not computed for since their 
concentration was not observed in the water samples. Absence of microbiological indicators in all the sampled swimming pools in Warri metropolis is a pointer to high level of compliance stipulated by WHO (2006). Nevertheless, this finding contradicts earlier report by Osei-Adjei et al., (2014) where all the microbiological indicators in sampled swimming pools in Osu-Labadi, Accra, Ghana were above WHO (2006) standards. A related study of swimming pools in Shahrekord City, Iran also had microbiological indicators higher than acceptable limit set by regulatory authorities (Fadaei and Amiri, 2015). In contrast, the finding corroborates the finding of Amala and Aleru (2016) where E. coli and S. aureus were conspicuously not discovered in all 10 sampled swimming pools in Port Harcourt metropolis. The authors further argued that this level can only be maintained with routine screening to avert possible contamination.

Similarly, it was found that the mathematical constant $(\mathrm{K})$ for $\mathrm{pH}$ was 7.813 , temperature (30.303), turbidity (0.5) and free (residual) chlorine (0.5). Although empirical evidence on the use of water quality index in assessing swimming pool water quality is lacking for result synthesis, the $\mathrm{K}$ factor for $\mathrm{pH}$ found in this study was higher than the value reported by Soleimani et al., (2018) while evaluating water quality used for consumption and irrigation in Kurdistan, Iran. With respect to unit weight (Wi) $\mathrm{pH}$ was 1.002, temperature (1.0101), turbidity (1) and free (residual) chlorine (1.01). Regarding Qi in Brook View Hotel, pH was - 75, temperature (83.3), turbidity (126) and Chlorine (13.3). Oasis Hotel recorded Qi of 50 for $\mathrm{pH}$, temperature (83.3), turbidity (370) and Chlorine (6.67).

BB Hotel had Qi of -100 for $\mathrm{pH}$, temperature (83.3), turbidity (216) and Chlorine (6.67). In Wellington Hotel recorded Qi of -112.5 for $\mathrm{pH}$, temperature (83.3), turbidity (32) and Chlorine (6.67). Wellington Hotel resulted in Qi of -87.5 for $\mathrm{pH}$, temperature (96.67), turbidity (144) and Chlorine (6.67). Again, the unit weight (Wi) for $\mathrm{pH}$ and turbidity discovered in this study was relatively higher than 0.322 for $\mathrm{pH}$ and 0.005 for turbidity report by Kumar and Dua (2009) while deploying water quality index in the evaluation of water quality of River Ravi, Madhopur, India. Also, Qi for free (residual) chlorine found in this work was higher than 0.105 reported by Rocha et al., (2015) while investigating the portability of water in Orós Reservoir (Northeast of Brazil) for drinking purpose.

The overall water quality index of the five sampled swimming pools as summarized in Table 5 showed that swimming pool located in Wellington Hotel had water quality index value of 2.52 and considered excellent in terms of water quality.

Table 5. Computed Water Quality Index of Sampled Hotels' Swimming Pools in Warri Source: Fieldwork, 2019

\begin{tabular}{|l|l|l|l|l|}
\hline S/No & Sampled Hotel & WQI & Standard Value & Classification \\
\hline 1. & Brook View & 36.9 & $26-50$ & Good water quality \\
\hline 2. & The Oasis Place & 102.1 & $>100$ & Unsuitable for recreational purpose \\
\hline 3. & BB Hotel & 51.4 & $51-75$ & Poor water quality \\
\hline 4. & Wellington Hotel & 2.52 & $0-25$ & Excellent water quality \\
\hline 5. & Best Western Plus & 39.9 & $26-50$ & Good water quality \\
\hline
\end{tabular}


Also, Brook View Hotel with water quality index of 36.9 and Best Western Plus with water quality index of 39.9 were categorized as good water quality. The excellent and good water quality observed in three out of the five sampled swimming pools may not be unconnected to the maintenance of high hygiene and sanitation standards by operators and swimmers. This implied that swimmers would have very little or no health hazard in any event of accidental swallowing of the swimming pool water. This finding corroborates with that of Egun and OgiesobaEguakun (2018) who reported excellent water quality (9.17-10.40) between February-June 2016 in Okhuaihe River, Edo State, Nigeria.

On the contrary, poor water quality (51.4) was reported in swimming pool owned and operated by BB Hotel while the swimming pool in The Oasis Place Hotel was categorized unsuitable for recreational purpose based on the water quality index of 102.1. Similarly, poor water quality, which was believed to have been caused by noticeable coloration, turbidity and dissolved salts, had previously been reported at the upper course of Orós Reservoir (Rocha et al., 2015). Concerted efforts are therefore needed by operators of these hotels to work on measures to improve the quality of water in the swimming pools in order to meet with established standard and fit for recreational purposes.

\section{Conclusion}

The quality of recreational water in many Nigerian cities cannot be neglected because of the risk and implications to human health. The prime motivation for carrying out this study was deploy the ingenuity offered by water quality index framework to provide a distinct score to the water quality of swimming pools in hotels in Warri metropolis. Water quality index facilitated the transformation of several indicators and their concentration present in a sample into a single value. These water quality index scores consecutively provided far-reaching explanation of the quality of water and its suitability for recreational purposes. One swimming pool water quality was categorized excellent, two were graded good, one each was ranked poor and unsuitable for recreational purpose whereas. The categorization of water quality of hotels' swimming pools water quality in Warri metropolis was facilitated by the deployment of Weighted Arithmetic Water Quality Index (WAWQI) framework.

At first sight, potential tourist, fun seekers, policy makers and other stakeholders can know the status of each swimming through the water quality index scores. Operators and managements of individual hotel and swimming pool can also use the index in facility-based evaluation of the extent of success and/or failure recorded so far while also exploring opportunities for improvement and sustainable water quality maintenance. The study therefore recommends routine and periodic surveillance of swimming pools and other recreational water sources to guarantee optimum health and wellbeing of users. This can be achieved through massive enlightenment by appropriate media and regulatory authorities. Also, effective institutional arrangement and governance framework capable of handling issues related to policies, proper legislation, enforcement, right systems, etc. should be put place in Warri metropolis and other emerging cities in Nigeria. 


\section{References}

Agbagwa, O., \& Young-Harry, W. (2012). Health implications of some public swimming pools located in Port Harcourt, Nigeria. Public Health Research, 2(6), 190-196. https://doi.org/10.5923/j.phr.20120206.03.

Aghoghovwia, O. A. (2011). Physico-chemical characteristics of Warri River in the Niger Delta region of Nigeria. Journal of Environmental Issues and Agriculture in Developing Countries, 3(2), 40-46.

Akoteyon, I. S., Omotayo, A. O., Soladoye, O., \& Olaoye, H. O. (2011). Determination of water quality index and suitability of urban river for municipal water supply in Lagos-Nigeria. European Journal of Scientific Research, 54(2), 263-271.

Amala, S. E., \& Aleru, C. P. (2016). Bacteriological quality of swimming pools water in Port Harcourt metropolis. Natural Science, 8(03), 79-84.

Anciaes, P., Metcalfe, P., \& Sen, A. (2020). A combined SP-RP model to estimate the value of improvements in freshwater angling in England. Journal of Environmental Economics and Policy, 9(2), 167-187.

Asadu, A. N. (2016). Assessment of Water Quality of Delta State, Agbarho Area, Nigeria. International Research Journal of Interdisciplinary \& Multidisciplinary Studies, 2 (4), 57-65.

Balan, I. N., Shiv Kumar, M., \& Madan Kumar, P. D. (2012). An Assessment of Groundwater quality using water quality index in Chennai, Tamil nadu, India, Chron Young Scientific, 3, 146-150.

Banda, T. D., \& Kumarasamy, M. (2020). Development of a Universal Water Quality Index (UWQI) for South African river catchments. Water, 12(6), 1534.

Barnett, M. J., Jackson-Smith, D., \& Haeffner, M. (2018). Influence of recreational activity on water quality perceptions and concerns in Utah: A replicated analysis. Journal of outdoor recreation and tourism, 22, 26-36.

Boelee, E., Geerling, G., van der Zaan, B., Blauw, A., \& Vethaak, A. D. (2019). Water and health: From environmental pressures to integrated responses. Acta tropica, 193, 217-226. https://doi.org/10.1016/j.actatropica.2019.03.011

Bonadonna, L., \& La Rosa, G. (2019). A review and update on waterborne viral diseases associated with swimming pools. International journal of environmental research and public health, 16(2), 166. https://doi.org/10.3390/ijerph16020166

Bora, M., \& Goswami, D. C. (2017). Water quality assessment in terms of water quality index (WQI): case study of the Kolong River, Assam, India. Applied Water Science, 7(6), 3125-3135.

Brown, R. M., Mccleiland, N. J., Deiniger, R. A., \& O'Connor, M. F. (1972). Water quality index-crossing the physical barrier,(Jenkis, SH, ed.) Proc. In Intl. Conf. on water poll. Res. Jerusalem (Vol. 6, pp. 787-797).

Chandra, D. S., Asadi, S. S., \& Raju, M. V. S. (2017). Estimation of water quality index by weighted arithmetic water quality index method: a model study. International Journal of Civil Engineering and Technology (IJCIET), 8(4), 1215-1222.

Chase, N. L., Sui, X., \& Blair, S. N. (2008). Swimming and all-cause mortality risk compared with running, walking, and sedentary habits in men. International Journal of Aquatic Research and Education, 2(3), 213-223.

Criteria and Water Quality Standards. Available at: https://www.epa.gov/standards-water-bodyhealth/relationship-between-water-quality-criteria-and-water-quality-standards (Retrieved on $20^{\text {th }}$ March, 2020).

Deanna Westby, M. (2001). A health professional's guide to exercise prescription for people with arthritis: a review of aerobic fitness activities. Arthritis Care \& Research: Official Journal of the American College of Rheumatology, 45(6), 501-511.

Delta State Hotels and Tourism Board (DSHTB, 2016). Unpublished Annual Hotel Registration Data. Asaba, DSHTB.

Department of Environment and Climate Change, Government of Newfoundland and Labrador (2016). Drinking Water Quality Index. Available at: http://www.ecc.gov.nl.ca/waterres/quality/drinkingwater/dwqi.html (Retrieved on 16 $16^{\text {th }}$ March, 2020).

Dirtu, D., Pancu, M., Minea, M. L., Chirazi, M., Sandu, I., \& Dirtu, A. C. (2016). Study of the quality indicators for the indoor swimming pool water samples in Romania. Rev. Chim.(Bucharest), 67(6), 1167-1171. 
Dunnette, D. A. (1979). A geographically variable water quality index used in Oregon. Journal (Water Pollution Control Federation), 53-61.

Efe, S. I., \& Efe, A. T. (2008). Spatial distribution of particulate matter (PM10) in Warri metropolis, Nigeria. The Environmentalist, 28(4), 385-394.

Egun, N. K., \& Ogiesoba-Eguakun, C. U. (2018). Physico-chemical and Water Quality Index analysis of the Okhuaihe River, Edo State, Nigeria. African Journal of Aquatic Science, 43(4), 345-351.

Enderlein, U. S., Enderlein, R. E. and Williams, W. P. (undated). Water Quality Requirements. Available at: http://www.who.int/water_sanitation_health/resourcesquality/wpcchap2.pdf (Retrieved on $16^{\text {th }}$ March, 2020).

Esinulo, A. C., \& Ogbuagu, D. H. (2016). Quality Assessment of Selected Public Swimming Pools in Owerri Metropolis, Nigeria. International Journal of Innovative Environmental Studies Research, 4(1), 28-34.

Eze, V. C., Onwuakor, C. E., \& Ikwuegbu, A. L. (2015). Microbiological and Physicochemical Characteristics of Swimming Pool Water in Owerri, Imo State, Nigeria. Journal of Applied \& Environmental Microbiology, 3(1), 6-10.

Fadaei, A., \& Amiri, M. (2015). Comparison of chemical, biological and physical quality assessment of indoor swimming pools in Shahrekord City, Iran in 2013. Global journal of health science, 7(3), 240-248.

Fovwe, O. D., Solomon, O., \& Ebhodaghe, O. F. (2014). An appraisal of groundwater quality in selected areas in Warri Metropolis. Journal of Water Resources and Ocean Science, 3(5), 55-60.

Fritzsche, K., Schneiderbauer, S., Bubeck, P., Kienberger, S., Buth, M., Zebisch, M., \& Kahlenborn, W. (2014). The Vulnerability Sourcebook: Concept and guidelines for standardised vulnerability assessments. Bonn, Deutsche Gesellschaft fur Internationale Zusammenarbeit (GIZ) GmbH. www.giz.de/climate (Retrieved on $6^{\text {th }}$ May, 2020)

Garcia, C. A. B., Silva, I. S., Mendonça, M. C. S., \& Garcia, H. L. (2018). Evaluation of Water Quality Indices: Use, Evolution and Future Perspectives. In Advances in Environmental Monitoring and Assessment. IntechOpen. https://doi.org/10.5772/intechopen.79408.

Godfrey, B. (2019). Five New Pool Construction Materials. Available at: https://www.lyonfinancial.net/fivenew-pool-construction-materials/ (Retrieved on $20^{\text {th }}$ October, 2020).

Horton, R. K. (1965). An index number system for rating water quality. Journal of Water Pollution Control Federation, 37(3), 300-306.

Kachroud, M., Trolard, F., Kefi, M., Jebari, S., \& Bourrié, G. (2019). Water quality indices: Challenges and application limits in the literature. Water, 11(2), 361. https://doi.org/10.3390/w11020361

Kaplan, J. (2014). Stratified Random Sampling. Available at: http://www.betterevaluation.org/en/evaluationoptions/stratifiedrandom (Retrieved on $15^{\text {th }}$ June, 2019).

Kumar, A., \& Dua, A. (2009). Water quality index for assessment of water quality of river Ravi at Madhopur (India). Global journal of environmental sciences, 8(1), 49-57.

Lotshaw, A. M., Thompson, M., Sadowsky, H. S., Hart, M. K., \& Millard, M. W. (2007). Quality of life and physical performance in land-and water-based pulmonary rehabilitation.Journal of cardiopulmonary rehabilitation and prevention, 27(4), 247-251.

Macrotrends LLC (2019). Warri, Nigeria Metro Area Population 1950-2020. Available at: https://www.macrotrends.net/cities/22023/warri/population/ (Retrieved on 28th March 2020).

Osei-Adjei, G., Sarpong, S. K., Laryea, E., \& Tagoe, E. (2014). Bacteriological quality assessment of swimming pools in the Osu-Labadi Area, Accra. Journal of Natural Sciences Research, 4(19), 126-129.

Pesewu, G. A., Boakye, A., Norshie, V., Adjei, D. N., Olu-Taiwo, M. A., Mills-Robertson, F. C., ... \& AyehKumi, P. F. (2015). Bacteriological Assessment of Water Quality of Public Swimming Pools in the Accra Metropolis, Ghana. Current Research Journal of Biological Sciences, 7(2), 31-36.

Rabi, A., Khader, Y., Alkafajei, A., \& Aqoulah, A. A. (2008). Sanitary conditions of public swimming pools in Amman, Jordan. International journal of environmental research and public health, 5(3), 152-157.

Rocha, F. C., Andrade, E. M., \& Lopes, F. B. (2015). Water quality index calculated from biological, physical and chemical attributes. Environmental monitoring and assessment, 187(1), 4163.

Saba, C. K. S., \& Tekpor, S. K. (2015). Water quality assessment of swimming pools and risk of spreading infections in Ghana. Research Journal of Microbiology, 10(1), 14. https://doi.org/10.3923/jm.2015.14.23 
Scannone, F. (2016). What is eutrophication? Causes, effects and control. Available at: http://www.eniscuola.net/en/2016/11/03/what-is-eutrophication-causes-effects-and-control/ (Retrieved on 28 $8^{\text {th }}$ March 2020).

Soleimani, H., Nasri, O., Ojaghi, B., Pasalari, H., Hosseini, M., Hashemzadeh, B., ... \& Feizabadi, G. K. (2018). Data on drinking water quality using water quality index (WQI) and assessment of groundwater quality for irrigation purposes in Qorveh\&Dehgolan, Kurdistan, Iran. Data in brief, 20, 375-386.

Stott, T. (2019). Water Sports and Water-Based Recreation. In: Outdoor Recreation. Palgrave Macmillan, Cham. Outdoor Recreation, 331-359. https://doi.org/10.1007/978-3-319-97758-4_13

Tyagi, S., Sharma, B., Singh, P., \& Dobhal, R. (2013). Water quality assessment in terms of water quality index. american Journal of water resources, 1(3), 34-38. https://doi.org/10.12691/ajwr-1-3-3

United Nations-Water (2014). Water Quality. Available at: http://www.un.org/waterforlifedecade/quality.shtml. (Retrieved on 20 th March, 2020).

United States Environmental Protection Agency (2016). Relationship between Water Quality

University of East Anglia-Climatic Research Unit (UEA-CRU), Harris, I. C. and Jones, P. D. (2019). CRU TS4.03: Climatic Research Unit (CRU) Time-Series (TS) version 4.03 of high-resolution gridded data of month-by-month variation in climate (January 1901 - December 2018). Centre for Environmental Data Analysis, 15 May, 2019. doi:10.5285/58a8802721c94c66ae45c3baa4d814d0.

World Health Organization (WHO, 2006). Guidelines for Safe Recreational Water environments. Volume 2, Swimming Pools and Similar Environments. Geneva, WHO.

World Health Organization (WHO, 2018). A global overview of national regulations and standards for drinking water quality. Geneva, World Health Organization; 2018. Licence: CC BY-NC-SA 3.0 IGO.

Yogendra, K., \& Puttaiah, E. T. (2008). Determination of water quality index and suitability of an urban waterbody in Shimoga Town, Karnataka. In Proceedings of Taal 2007: The 12th world lake conference (342-346). 